\title{
PERFORMANCE ANALYSIS OF ALUMINUM INDUSTRY BASED ON PRODUCT LIFE CYCLE AND MARKET TRENDS
}

\author{
Saiqa Ilham Akbar ${ }^{1}$, Anisa Nurpita ${ }^{2}$ \\ ${ }^{1}$ Diploma IV in Banking, ${ }^{2}$ Diploma IV in Management and Property \\ Appraisal, Department of Economics and Business, Vocational School, \\ University of Gadjah Mada, Indonesia
}

\begin{abstract}
This study tries to measure the performance of aluminum and small and medium industries (SMEs) in Yogyakarta which are considered to be underdeveloped. Based on the development of the number of businesses, over the past ten years the number of SMEs has continued to decline. Based on these conditions, this study tries to use the industry life cycle approach and market trends to analyze the position of the aluminum industry in Yogyakarta City in particular and Indonesia in general to measure the performance of the industry. Descriptive analysis results collected through written questionnaires are complemented by content analysis of the results of interviews and focus group discussions (FGD) with stakeholders to get more in-depth information to draw conclusions from and provide suggestions for the development of aluminum SMIs in the city of Yogyakarta. The results obtained from this study is that the aluminum industry in the city of Yogyakarta is in an early maturity position, so it needs a strategy to extend the industrial life cycle. This research is still limited to one industrial center and is discussed from the perspective of SMIs, the next research will produce more comprehensive results with data from several industrial centers and involve large industries to get a more complete view of the relations between industries. This research is one of the few studies that discuss the performance of the industry in terms of product life cycle in Indonesia which is a fairly good approach in developing development strategies and to help the industry survive.
\end{abstract}

Keywords: SME, product life cycle, market trend, industry performance.

\section{INTRODUCTION}

Economic development in the city of Yogyakarta in general has brought progress in various business sectors including the manufacturing industry which

\footnotetext{
*Corresponding Author.

e-mail: saiqailham88@ugm.ac.id
} 
is the foremost contributor to the Gross Regional Domestic Product (GRDP) of Yogyakarta City by $13.47 \%$ in 2017 with the largest contribution being in the sub-industry of Food and Beverage with a contribution of $7.72 \%$, followed by the Metal Products sub sector; Computer; Electronic goods; Optics; and Electrical Equipment with a contribution of $2.33 \%$ of the Yogyakarta City GRDP based on the business field in 2017. In terms of quantity, the Processing Industry in Yogyakarta City subsequently formed a lot from SMIs and one of the parts of SMI related to metal processing is the Aluminum SMIs.

The aluminum industry has a slightly different character from industries such as silver and gold which can be directly attributed to economic growth, in which case Yogyakarta is much supported by tourism growth whereas the flexibility of the Aluminum industry is slightly lower compared to gold and silver especially regarding souvenirs.

When product flexibility is the most important issue in the Aluminum industry, the actual existence of product innovation is an important factor that determines the sustainability of the aluminum industry. The ability to see opportunities, the skills to modify the model according to market demands, and the improvement of business management in accordance with the current demands. The success of product development is determined by four key success factors, namely the high quality of new product processes, understanding of new product strategies at every level of the company, commitment of resources, namely human resources and funds, and the ability of the research and development department (R\&D) in initiating new product development. Successful product development will have an impact on the production of superior products (Indriani, 2006).

At first glance, considering the trend of processing aluminum on a large scale, you will see a shift in the use of ferrous metals into aluminum. Pedal bikes, motorcycle and car components, alloy wheels, furniture, trellis, and accessories start using Aluminum parts because of corrosion and weight considerations. However, this trend has not yet been strongly applied in the medium and smallscale Aluminum (SME) manufacturing industry, which is generally still in the form of casting, smelting and household equipment manufacturing activities. Previous researches show that life cycle stages influence management decisions in their investment strategies (Gumanti \& Puspitasari, 2008). 
The biggest challenge in the Aluminum industry in the city of Yogyakarta is finding its own core of growth which in the current conditions is not an easy step. The life cycle of Aluminum products must be renewed with innovations that are adapted to market trends. There are several things that need to be considered in understanding the development of the aluminum metal industry at the Yogyakarta City Aluminum SMI, such as the development of the Yogyakarta City Aluminum SMI human resource, which is currently experiencing significant problems and challenges in line with the rapid changes in the business environment, both local, regional, and international . Second, the era of economic globalization accompanied by rapid technological development has an impact in the form of intense competition and rapid changes in the business environment. Next, the movement of market trends that tend to use goods with increasingly modern engineering technology, providing higher quality and economical results from goods produced by the Yogyakarta City Aluminum SMI today. Finally, capital constraints in most of the Yogyakarta City Aluminum SMI, especially in the form of equipment that inhibits business growth, especially in the ability to create new product innovations according to market tastes.

The main prerequisites for the continuous development of strategic business units and/or companies are the willingness and ability of management to receive new knowledge about the interdependence between business goals and the interdisciplinary knowledge needed to achieve them (Sabol, Sander \& Fuckan, 2013). Other research shows that 108 partner manufacturing partners in East Java, using multiple regression analysis, provide results where jointly implementing resource-based strategies and innovations will achieve product competitive advantage. But in terms of its contribution to resources, there are only three resources, physical resources, product innovation, and internal resources, which greatly contribute to increasing product competitive advantage (Prasetyo, 2008).

Considering the existing market conditions and the constraints faced by the Yogyakarta City Aluminum SMI, it can be said that the Aluminum SMIs in the City of Yogyakarta is facing a serious problem that threatens the sustainability of their business to a certain degree so that a deeper analysis of the real conditions and problems is needed. This might cause bankruptcy for currently existing Aluminum SMIs. 


\section{LITERATURE REVIEW}

\subsection{Industry and SMI}

The industrial sector is one of the key sectors in enhancing the national economy (Lestari, 2010). The statement is supported by several reasons, the first is that the industry is the sector that can produce the greatest added value and give high contribution to the growth of Gross Regional Domestic Product (GRDP). Second, the industry can be an attractor (through backward linkages of production) and a driver (through future linkages of production) to the development and growth of output in other economic sectors. Third, the industry is the most important sector for technology development which can then be spread through spillover effects to other sectors. This has been proven by countries undergoing an industrial revolution whose economic growth tends to increase rapidly.

Unlike the industries in developed countries, industries in Indonesia are dominated by small and medium industries (SMI). According to the Regulation of the Minister of Industry of the Republic of Indonesia No. 64 year 2016, industry is defined as any form of economic activity that processes raw materials and/or utilizes industrial resources so as to produce goods that have added value or higher benefits, including industrial services. The regulation also outlines the classification of industries into small, medium, and large industries. Small industry is an industry that employs a maximum of 19 workers with an investment of less than one billion rupiahs, excluding land and buildings. While the medium industry is an industry that employs at least 20 people with an investment of less than fifteen billion rupiahs. Finally, large industries are industries that employ at least 20 people with an investment of more than fifteen billion rupiahs. The industrial classification is presented in Table 1 below.

Table 1 Classification of Small, Medium, and Large Industries

\begin{tabular}{l|ll}
\hline Industry Classification & \multicolumn{1}{|c}{ Size of Workforce } & \multicolumn{1}{c}{ Investment Value } \\
\hline Small industry & $\leq 19$ people & $\leq \mathrm{Rp} \mathrm{1.000.000.000}$ \\
Medium industry & $19-20$ people & $\mathrm{Rp} \mathrm{1.000.000.000-15.000.000.000}$ \\
Large industry & $\geq 20$ people & $>\mathrm{Rp} \mathrm{15.000.000.000}$ \\
\hline
\end{tabular}

Source: Regulation of the Minister of Industry No. 64 Year 2016 
Characteristics of SMI in Indonesia according to the Director General of SMI from thr Ministry of Industry (2006) include micro scale, spread throughout Indonesia, which value of investment is relatively small, produces high added value, low barrier to entry, uses simple technology to intermediate, does not require high expertise, is a source of new entrepreneurial creation, has a high degree of flexibility in dealing with changing market dynamics, and is resistant to the turmoil of the economic crisis. From the characteristics of SMEs that have been mentioned, some of them are characteristics that are considered superior compared to what is in large industries. First, the SMI has a barrier to entry into the industry that is low in both investment value and applied technology so that it is suitable to encourage the economy of many people by increasing public participation in industries that are considered potential. Second, SMI organizations tend to be small and not involve many people so that it is easy to produce new innovations and improvisations to deal with market dynamics so that they are known to have good flexibility and are resistant to economic shocks. Third, because of its labor-intensive nature and moderate expertise requirement, SMEs become a mainstay in increasing employment in the community.

The development of SMI itself, although important, is not immune to the classic problems that accompany it. SMIs in Indonesia generally face problems in terms of capital and access to funding, quality and cheap raw materials, technological limitations, limited human resources with good managerial and financial expertise, and market and marketing access. These problems are compounded by increased competition caused by globalization. If not immediately addressed, these may cause fatal consequences, one of which may lead to the bankruptcy of industries in a region because they are unable to compete.

\subsection{Life Cycle of Industry and Products}

The concept of the industrial life cycle was first introduced by Michael Porter in 1980. Based on this concept, the industry is an important part of the corporate environment. Industry characteristics will influence the level of competition and the structure of the industry can affect the competition rules that exist in it so that various strategies to survive and compete in the industry are developed to answer any challenges that exist in the industry (Sabol, Sander, \& 
Fuckan, 2013). Based on its life cycle, industrial conditions can be divided into four stages, namely introduction, growth, saturation, and decline. Each of these stages has several characteristics but its main characteristic can be illustrated through the level of sales and age of the industry.

A perfectly developed industry will generally experience all four stages before they will eventually disappear with the decline in the industry. Several theories are developed related to efforts to extend the life of the industry, one of which is done by intervening in the decline stage so that the industry can

Table 2 Parameter of Industry Position on Industrial Life Cycle

\begin{tabular}{|c|c|c|c|c|}
\hline & Introduction & Growth & Mature & Decline \\
\hline Demand & $\begin{array}{l}\text { Limited to early } \\
\text { adopters and } \\
\text { high-income } \\
\text { consumers }\end{array}$ & $\begin{array}{l}\text { Demand is increasing } \\
\text { rapidly }\end{array}$ & $\begin{array}{l}\text { Many repeat } \\
\text { purchases occur, } \\
\text { and consumers have } \\
\text { begun to be } \\
\text { sensitive to prices }\end{array}$ & $\begin{array}{l}\text { Demand begin } \\
\text { to decline }\end{array}$ \\
\hline Technology & $\begin{array}{l}\text { Compete in } \\
\text { technology and } \\
\text { product } \\
\text { innovation } \\
\text { quickly }\end{array}$ & $\begin{array}{l}\text { Began to lead to } \\
\text { standardization to } \\
\text { one of the } \\
\text { technologies and } \\
\text { innovation focused } \\
\text { on the process }\end{array}$ & $\begin{array}{l}\text { The technology } \\
\text { used has all been } \\
\text { used, starting to } \\
\text { focus on } \\
\text { technological } \\
\text { innovation }\end{array}$ & $\begin{array}{l}\text { Innovation in } \\
\text { product and } \\
\text { process } \\
\text { innovation mulai } \\
\text { sedikit/jenuh. }\end{array}$ \\
\hline Product & $\begin{array}{l}\text { Quality is not } \\
\text { good, many } \\
\text { features, and } \\
\text { many design } \\
\text { changes }\end{array}$ & $\begin{array}{l}\text { Design and quality } \\
\text { increase, superior } \\
\text { designs are becoming } \\
\text { more widely used }\end{array}$ & $\begin{array}{l}\text { Starting to become } \\
\text { a commodity. } \\
\text { Competition } \\
\text { through differentia- } \\
\text { tion and branding. }\end{array}$ & $\begin{array}{l}\text { Differentiation } \\
\text { begins to be } \\
\text { difficult and } \\
\text { unprofitable }\end{array}$ \\
\hline $\begin{array}{l}\text { Manufacturing } \\
\text { and } \\
\text { Distribution }\end{array}$ & $\begin{array}{l}\text { Short production } \\
\text { period, high } \\
\text { skilled workforce } \\
\text { requirements, spe- } \\
\text { cial distribution } \\
\text { channels }\end{array}$ & $\begin{array}{l}\text { Limited capacity, } \\
\text { mass production, and } \\
\text { competing for } \\
\text { distribution channels }\end{array}$ & $\begin{array}{l}\text { Began to appear } \\
\text { over capacity, no } \\
\text { longer requires } \\
\text { special abilities, } \\
\text { distribution began } \\
\text { to be limited }\end{array}$ & $\begin{array}{l}\text { Over capacity is } \\
\text { severe, } \\
\text { distribution } \\
\text { begins to return } \\
\text { to special } \\
\text { channels }\end{array}$ \\
\hline Trade & $\begin{array}{l}\text { Both producers } \\
\text { and consumers are } \\
\text { in developed } \\
\text { countries }\end{array}$ & $\begin{array}{l}\text { Exports from } \\
\text { developed countries } \\
\text { to all over the world }\end{array}$ & $\begin{array}{l}\text { Production began } \\
\text { to shift to } \\
\text { developing } \\
\text { countries }\end{array}$ & $\begin{array}{l}\text { Exports from } \\
\text { the country with } \\
\text { the lowest labor } \\
\text { force }\end{array}$ \\
\hline Competition & Few competitors & $\begin{array}{l}\text { Many new players, } \\
\text { mergers, and closures }\end{array}$ & $\begin{array}{l}\text { The cost of } \\
\text { competition is } \\
\text { increasing }\end{array}$ & $\begin{array}{l}\text { Price war, many } \\
\text { players out of } \\
\text { the industry }\end{array}$ \\
\hline $\begin{array}{l}\text { Key Success } \\
\text { Factors }\end{array}$ & $\begin{array}{l}\text { Product } \\
\text { innovation, } \\
\text { credible image } \\
\text { development }\end{array}$ & $\begin{array}{l}\text { Manufacturing } \\
\text { design, access to } \\
\text { distribution, brand } \\
\text { building, rapid pro- } \\
\text { duct development, } \\
\text { process innovation }\end{array}$ & $\begin{array}{l}\text { Cost efficiency } \\
\text { through capital } \\
\text { intensification, } \\
\text { economies of scale, } \\
\text { low input costs }\end{array}$ & $\begin{array}{l}\text { Low overhead, } \\
\text { buyer selection, } \\
\text { commitment } \\
\text { signaling, and } \\
\text { capacity } \\
\text { rationalization }\end{array}$ \\
\hline
\end{tabular}

Source: Sabol, Sander, \& Fuckan (2013) 
continue to survive. While the behavior of industries that have lived long enough based on their performance is divided into four categories developed by Maksimovic and Phillips (2008), namely growth industries, consolidated industries, industries with technological changes, and industries that have fallen. The four categories developed by Maksimovic and Phillips describe the long-term condition of an industry as seen from the overall industrial production conditions and the number of companies in the industry.

Based on Sabol, Sander, \& Fuckan (2003) industry classifications based on their life cycle can be distinguished from several parameters, namely demand, technology, products, manufacturing and distribution, trade, competition, and key success factors. In summary, the classification of these industries can be seen from Table 2.

Slightly different from the industrial life cycle, primarily the product life cycle can be distinguished from one to another through the conditions of sale and cost. Starting from the research and development stage, which is characterized by high research costs and no sales. Second, the sales introduction stage, which has low sales, but the costs are still higher than sales. Third, at the stage of growth where sales began to increase rapidly while costs began to become more economic. Fourth, at the saturation stage, sales start to reach its peak and costs have begun to reach an economic point for some actors. Finally, at the stage of decline, sales begin to decline with low costs but no longer at the economic point due to over capacity.

In addition to the two parameters used in classifying stages of the product life cycle, there are several other parameters that also describe the different conditions in each product life cycle such as profitability, consumers, and competitors. In full, the classification of product life cycle stages based on Claessens (2013) is shown in Table 3.

Table 3 Product Life Cycle Classification

\begin{tabular}{l|llll}
\hline & \multicolumn{1}{|c}{ Introduction } & \multicolumn{1}{c}{ Growth } & \multicolumn{1}{c}{ Mature } & Decline \\
\hline Sales & Low & Significantly increasing & High, peaking & Declining \\
Cost & High cost per customer & Medium cost per customer & Low cost per customer & $\begin{array}{l}\text { Low cost per } \\
\text { customer }\end{array}$ \\
& & & & High \\
Profit & Negative & Increasing & Majority & Outdated customers \\
Pelanggan & Innovators & Early adopters & Numerous and stable & Declining \\
Pesaing & Few & Increasing & & \\
\hline
\end{tabular}




\section{RESEARCH METHODOLOGY}

This research is a descriptive inductive study which tries to understand the problems at the level of industrial business actors to be generalized in a more general context. The data used in this study include secondary and primary data. Secondary data includes written data and information related to aluminum SMIs in the city of Yogyakarta. Meanwhile, the primary data in this study are data obtained directly from respondents through face-to-face interviews, joint discussions in a forum (Focus Group Discussion), or using structured questionnaires to extract data using questionnaires as a guide to interview respondents directly.

In conducting field research, the use of appropriate sampling methods is needed in order to obtain precise and accurate data in support of data analysis so that optimal research results can be obtained. Based on the results of preliminary information gathering, it is known that the number of aluminum SMIs that are still active in the city of Yogyakarta is 67 business units. From this population, it is hoped that a sample can be obtained that is used to infer or describe the population as a whole. To get the right sample proportions, the Slovin formula (Sevilla et al. 1960: 182) is used as follows:

$$
n=\frac{N}{1+N \theta^{2}}
$$

With information $n$ is the number of samples, $N$ is the number of populations, and $e$ is the error tolerance limit. Sampling technique is done by using a random sampling method by registering the entire population and taking random samples based on random numbers generated using Microsoft Excel.

There are several analytical tools used in this study, the first is descriptive statistical analysis. Descriptive statistical analysis is intended for grouping data based on the variables studied and tabulating data based on variables obtained from all respondents. Descriptive statistics, as the name suggests, intends to describe the data that has been collected without generalizing. In general, quantitative research does seek to be generalized, however, if the researcher only wishes to calculates the data that applies to the sample under study, the researcher uses descriptive statistics. This analysis is considered appropriate for use in this study because this study is a case study and there is no need for generalization to a greater extent by using inferential statistics. 
The second analysis tool is content analysis which is a procedure for categorizing verbal or behavioral data with the aim of classifying, inferring, and tabulating. Content analysis is carried out to process data obtained from the results of in-depth interviews and FGDs that have been transcribed verbatim into unstructured text.

\section{RESULTS AND DISCUSSION}

Based on the results of the analysis that has been done both on secondary data and primary data, the discussion will focus on two main subjects, namely related to product life cycle and market trends of aluminum products produced by aluminum SMIs in the city of Yogyakarta. The discussion of product life cycle is emphasized on the position of aluminum products produced by SMIs at the product life cycle stage which consists of introduction, growth, saturation, and decline. While the discussion related to market trends is emphasized on the growth trends of the products currently produced and the direction of the development of market preferences for aluminum-derived products in the city of Yogyakarta and surrounding areas.

\subsection{Respondents’ Profile}

Based on preliminary information from UPT Metals and Cooperatives, there were 71 SMI Aluminum data in Yogyakarta City, mostly in the Nitikan Subdistrict. After the sampling, a survey of 34 SMIs in the list was carried out. Based on the sex of the respondents in this study most of the respondents were men with a ratio of $64.71 \%$ male and $35.29 \%$ female. The majority of respondents who filled out the questionnaire were the direct owners of the Aluminum SMIs referred to as a percentage of $94.12 \%$ while the $2.94 \%$ of the other respondents were employees and the remaining 2.94\% were families of the SMI owners.

Based on the level of education, the majority of respondents was found to have completed nine years of basic education, only $20.59 \%$ who graduated from elementary school, 2.94\% who did not complete primary school, and 5.88\% 
who did not attend school. Nearly half of the respondents were $41.18 \%$ high school graduates and $14.71 \%$ college graduates.

Respondents who filled out the questionnaire were also divided based on the age of the respondents into five categories, under 31 years, 31-40 years, 41-50 years, 51-60 years, and above 60 years. The age of respondents who filled out the questionnaire the most was respondents are aged between 51 and 60 as many as $35.3 \%$, followed by respondents aged between 31 and 40 years as many as $26.5 \%$. There were $20.6 \%$ of respondents aged 41 to 50 years and $14.7 \%$ aged over 60 years. Only $2.9 \%$ of respondents are under the age of 31 years. Based on the age profile of the respondents it can be seen that half the respondents were more than 50 years old when the survey was conducted.

\subsection{Industry Profile}

The industry profiles surveyed were identified to understand the characteristics of the aluminum industry in the City of Yogyakarta. Based on Figure 4.2, it is known that the majority of the aluminum industry in the city of Yogyakarta has not yet formed a business entity or business legal entity. Some are still in the form of SMEs that are individually based, there are only $1.3 \%$ in the form of CVs and $1.3 \%$ in the form of cooperatives. Based on their age, the aluminum SMIs that were sampled in this study were categorized into 5 age categories, namely 1-10 years, 11-20 years, $21-30$ years, $31-40$ years and over 40 years.

The youngest SMI is 3 years old and the longest standing is 41 years old with the average SMI age of 21.62 years. There are $29.4 \%$ of SMIs aged between 11 and 20 years, $23.5 \%$ aged between 31 to 40 years and 1 to 10 years, 20.6\% aged 21 to 30 years, and $2.9 \%$ aged over 40 year. The SMI profile can also be seen from the number of employees, which is divided into five categories, the number of employees between 1-5 people, 6-10 people, 11-15 people, 16-20 people, and above 20 people.

The number of employees owned by Aluminum SMIs in the city of Yogyakarta ranges from 1 to 125 employees with an average of 9.49 employees. Most SMIs that become respondents have a number of employees between 1-5 people, 32.4\% have a number of employees between 6-10 employees, 5.9\% have employees between 11-15 people and between 16-20 people, and as many as 
$2.9 \%$ have more than 20 employees. It means that on industry classification based on the number of workers, there are a number of SMEs who are already classified as large industries.

\subsection{Analysis Results of Product Life Cycle}

For the products produced by aluminum SMIs in Yogyakarta City, some of the results of the analysis show signs that the aluminum products produced to be in a position of growth and some others show signs/symptoms that the product has reached the saturation stage. The results of the analysis of product characteristics at each stage of the product life cycle are shown in the following Table 4.

Table 4 Results of Analysis of Characteristics of Aluminum SMI Products

\begin{tabular}{c|llcl}
\hline No. & \multicolumn{1}{|c}{ Characteristics } & \multicolumn{1}{c}{$\begin{array}{c}\text { Majority of } \\
\text { Answers }\end{array}$} & Percentage & $\begin{array}{c}\text { Indication } \\
\text { of Stage }\end{array}$ \\
\hline 1 & Sales Volume & Low Growth & $47,1 \%$ & Saturation \\
2 & Production Cost & Medium & $52,9 \%$ & Growth \\
3 & Profit Level & Stable & $61,8 \%$ & Saturation \\
4 & Number of Competitors & Numerous & $58,8 \%$ & Saturation \\
5 & Product Variants & Few & $76,5 \%$ & Growth \\
6 & Price Setting & Margin Price & $32,4 \%$ & Growth \\
9 & Customer & Common Majority & $58,8 \%$ & Saturation \\
\hline
\end{tabular}

Source: Processed primary data

Based on the product life cycle analysis that was carried out, it appears that aluminum products produced by aluminum SMIs in the city of Yogyakarta are in a position between the growth stage and the saturation stage with four signs indicating the position at the saturation stage and three signs indicating the position at the growth stage. This analysis is reinforced by the few facts found in the survey which show that although the average monthly turnover for all SMIs in the City of Yogyakarta has increased in the last three years, different results emerged when large SMIs were excluded from the sample. In other words, in small scale aluminum SMIs there was a decline in sales value in the last three years. In addition, concerns began to emerge from the performance of substitute products on the market, as well as the importance of efficiency in the production of aluminum products showing a strong enough symptom that the 
aluminum products produced by aluminum SMIs in the city of Yogyakarta had reached the saturation stage. Based on the results of the interim analysis, it can be said that the aluminum products produced by aluminum SMIs in the city of Yogyakarta are at the beginning of the saturation stage which is more or less depicted in the following figure.

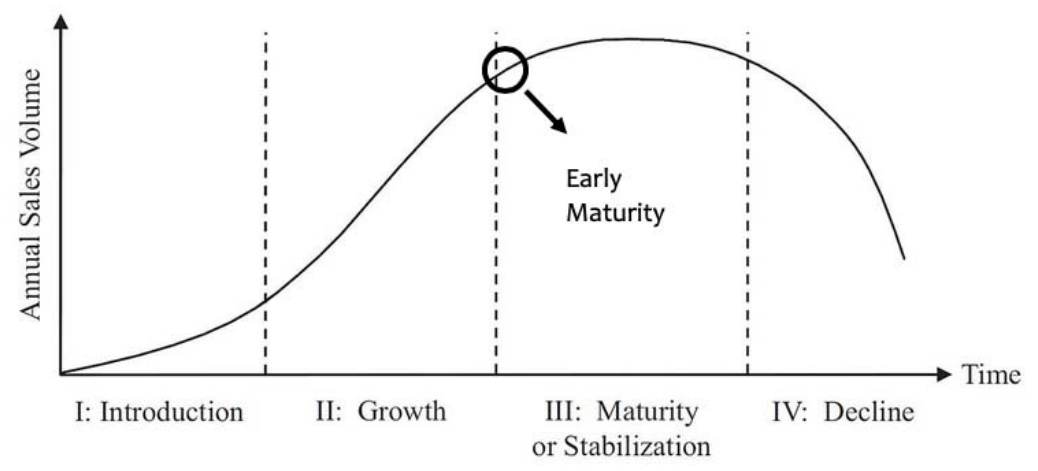

Figure 1 Aluminum SMIs Position in Industrial Life Cycle

This position at the beginning of saturation needs to be strengthened by increasing industrial performance. Based on the survey results, $14.6 \%$ of SMIs stated that improving industrial performance can be done by improving the quality of the products produced. This was also reinforced by other opinions which stated the need for assistance/training in various matters in the aluminum industry to improve their competitiveness.

There are two strategies that need to be done to maintain the competitiveness of products that have begun to enter the saturation stage, which is to extend the product life cycle and extend the saturation stage of the product or industry. The two strategies have two different approaches in extending product life cycles so that they last longer in the market. In the strategy of extending product life cycles, efforts can be made to improve quality and add product features, target new markets or market segments, and bundle products with other products.

In the strategy of maintaining the product at the saturation stage, the efforts made are more to delay the emergence of the decline phase, such efforts include making product improvements, making efficiencies, and still trying to adjust to existing trends. 
Of the two strategies, there are several conditions where the first strategy is more suitable than the second strategy. Some of these conditions include the product must still have an appeal, the motivation to invest, the product is not too deep in the saturation stage, and the product quality is quite good. Whereas some conditions that are more in line with the second strategy include if the product is no longer so attractive, investment capacity is limited, and it has been in the saturation stage for a long time.

\subsection{Analysis Results of Market Trends}

The next discussion is related to the market trends of aluminum products produced by aluminum SMEs in the City of Yogyakarta. Although in certain product variants there has been a decreasing trend in demand, overall, in each aluminum product category that was produced there was no sign of a significant decrease in market demand. For example, in the aluminum product category in the form of cooking utensils, although in some variants of cake molds have decreased, cake molds with other variants are still being produced and even new variants appear. This change in trend is more in line with the cycles or seasonal patterns of the food industry and is not a change in trends in aluminum cookware products in general.

In terms of sales turnover, overall industry sales trends show an increase even though the majority of these increases are contributed by large-scale SMEs. This shows that the decline in turnover in some SMIs is more due to market competition and production efficiency based on the economies of scale of each SME. This opinion was confirmed from the results of content analysis which showed that the majority of aluminum SMIs in the city of Yogyakarta did not feel a decline in the aluminum industry in general.

Based on the results of content analysis, only 38.7\% thought that the industry declined while another $38.7 \%$ thought there was no decline and another $22.6 \%$ actually stated that the aluminum industry in the city of Yogyakarta had increased. Furthermore, the dominating opinion related to the signs of decline is considered more as a factor of business competition and the quality of products produced by each Aluminum SMIs in the City of Yogyakarta. This competition 
also makes business margins lower so that some SMEs choose to stop producing because they are unable to keep up with the price competition.

The stable trend of market demand for aluminum products in the city of Yogyakarta is supported by information that the majority of SMEs sell products through large traders so that they are not directly affected by direct market demand. In this case, the marketing role of SMEs to their own products is limited because the role of product marketing is mostly done by large traders considering that in terms of brand differentiation, it is still lacking in aluminum products in Yogyakarta City.

Based on available data, the decline in the performance of aluminum SMIs in the city of Yogyakarta is more the declining competitiveness of small scale SMIs relative to the development of large SMIs in the aluminum industry center. The declining performance is unconfirmed from the effect of a direct decline in market trends. Based on these causes, there were several suggestions for local governments as industrial policy makers as obtained from content analysis. There were 6 suggestions that came up most from respondents, namely Assistance/ training, Capital assistance, Aid tools, Increasing attention to small-scale businesses, Marketing, and permits made easier.

\section{CONCLUSION}

The condition of aluminum SMIs in the City of Yogyakarta that was successfully identified in this study showed a stable condition different from the indications captured earlier. Although there is a decrease in the number of SMIs in operation, there are still a number of new SMIs that have emerged. Some SMIs that stop operating are also more due to internal problems.

The product life cycle analysis results show that the aluminum SMIs' products in the city of Yogyakarta are in the early maturity stage. In this condition, several efforts can still be made to improve the performance of the industry so that it can avoid industry bankruptcy in the near future. Based on the characteristics of the industry that were captured, a strategy to maintain industrial competitiveness that can be done is a strategy to extend the product life 
cycle. Some of the efforts that can be done include improving quality and adding product features, targeting new markets or market segments, bundling products with other products, and increasing efficiency.

Also, from the side of the market trend, there is also unconfirmed decline in market trends that would drive the bankruptcy of aluminum SMIs in the city of Yogyakarta in the near future. Some signs of decreasing performance of aluminum SMIs in the city of Yogyakarta that appear so far are more due to competition and the dynamics of existing industries that tend to be more profitable for large SMIs.

However, it is also important to identify factors in terms of product life cycle and market trends which are considered to be obstacles in improving the performance of aluminum SMIs in the city of Yogyakarta, including the increasing number of substitute products, the use of more modern technology, the number of competitors, and standards of product quality.

It can be concluded in general that in the near future aluminum SMIs in the city of Yogyakarta will not experience bankruptcy and can improve their competitiveness if they can make improvements in the operational scope of each SMI and make improvements to the existing aluminum industry's competitiveness through increasing inter-industry value chains.

\section{REFERENCE}

Claessens, M. 2013. Product Life Cycle Strategies (PLC) and Characteristics Managing each PLC Stage. Marketing Explained.

Gumanti, T.A. \& Puspitasari, N. 2008. Siklus Kehidupan Perusahaan dan Kaitannya dengan Investment Opportunity Set, Risiko, dan Kinerja Finansial. Jurnal Riset Ekonomika dan Bisnis, 8(1), 37-49.

Indriani, F. 2006. Studi Mengenai Orientasi Inovasi, Pengembangan Produk dan Efektivitas Promosi sebagai Sebuah Strategi untuk Meningkatkan Kinerja Produk. Jurnal Studi Manajemen dan Organisasi, 3(2), 82-92.

Lestari, E.P. 2010. Penguatan Ekonomi Industri Kecil dan Menengah melalui Platform Klaster Industri. Jurnal Organisasi dan Manajemen, 6(2), 146157. 
Review of Management and Entrepreneurship

Volume 03, Number 02, October 2019

Maksimovic, V. \& Phillips, G. 2008. The Industry Life Cycle, Acquisitions, and Investment: Does Firm Organization Matters. Journal of Finance, 63(2), 673-708.

Sabol, A., Sander, M., \& Fuckan, D. 2013. The Concept of Industry Life Cycle and Development of Business Strategies. Presented at 2013 Management, Knowledge, and Learning International Conference Make Learn, Zagreb. 